\title{
Mixing and photoreactivity of dissolved organic matter in the Nelson/Hayes estuarine system (Hudson Bay, Canada)
}

\author{
C. Guéguen ${ }^{\mathrm{a}, *}$, M. Mokhtar $^{\mathrm{a}}$, A. Perroud ${ }^{\mathrm{a}}$, G. McCullough ${ }^{\mathrm{b}}$, T. Papakyriakou ${ }^{\mathrm{b}}$ \\ a Department of Chemistry, Trent University, Peterborough, Ontario, K9J 7B8, Canada \\ ${ }^{\mathrm{b}}$ Centre for Earth Observation Science, University of Manitoba, Winnipeg, Manitoba, R3T 2N2, Canada
}

\section{A R T I C L E I N F O}

\section{Article history:}

Received 19 January 2016

Received in revised form 24 May 2016

Accepted 25 May 2016

Available online 4 June 2016

\section{Keywords:}

Estuarine mixing

PARAFAC

DOM

Photoirradiation

Spectral slope

\begin{abstract}
A B S T R A C T
This work presents the results of a 4-year study (2009-2012) investigating the mixing and photoreactivity of dissolved organic matter (DOM) in the Nelson/Hayes estuary (Hudson Bay). Dissolved organic carbon (DOC), colored DOM, and humic-like DOM decreased with increasing salinity $\left(r^{2}=0.70-0.84\right)$. Removal of DOM was noticeable at low to mid salinity range, likely due to degradation and/or adsorption to particles. DOM photobleaching rates (i.e., decrease in DOM signal resulting from exposure to solar radiation) ranged from 0.005 to $0.030 \mathrm{~h}^{-1}$, corresponding to half-lives of 4.9-9.9 days. Dissolved organic matter from the Nelson and Hayes Rivers was more photoreactive than from the estuary where the photodegradation of terrestrial DOM decreased with increasing salinity. Coincident with the loss of CDOM absorption was an increase in spectral slope S, suggesting a decrease in DOM molecular weight. Marked differences in photoreactivity of protein- and humic-like DOM were observed with highly humidified material being the most photosensitive. Information generated by our study will provide a valuable data set for better understanding the impacts of future hydroelectric development and climate change on DOM biogeochemical dynamics in the Nelson/Hayes estuary and coastal domain. This study will constitute a reference on terrestrial DOM fate prior to building additional generating capacity on the Nelson River.
\end{abstract}

(c) 2016 Elsevier B.V. All rights reserved.

\section{Introduction}

As the largest inland sea in the world, Hudson Bay receives a cumulative annual discharge of $\sim 710 \mathrm{~m}^{3} \mathrm{yr}^{-1}$ from 42 rivers (Déry et al., 2005). The Nelson River (southwest Hudson Bay) contributes as much as $34 \%$ of the total freshwater into Hudson Bay. The presence of hydroelectric development has also altered the timing and magnitude of river discharge to the coastal environment (Déry et al., 2005). Collecting baseline data constitutes a pre requisite prior to building additional generating capacity on the Nelson River. The total annual export of riverine dissolved organic carbon (DOC) is estimated at $\sim 5.5 \mathrm{Tg} \mathrm{C} \mathrm{yr}^{-1}$ (Déry et al., 2011), representing approximately $23 \%$ of the annual input of Arctic rivers draining directly into the Arctic Ocean (Mundy et al., 2010). The spatial distribution of chromophoric and fluorescent dissolved organic matter (CDOM and FDOM, respectively) in the Hudson Bay system has been described (Granskog et al., 2009, 2011; Granskog, 2012; Guéguen et al., 2011) and has revealed the predominance of terrestrially derived DOM (up to 89\%) in Hudson Bay surface waters.

\footnotetext{
* Corresponding author.

E-mail address: celinegueguen@trentu.ca (C. Guéguen).
}

Estuaries are particularly important for the carbon cycle as they constitute the interface between terrestrial and marine ecosystems where DOM is subject to biotic and abiotic transformations due to abrupt changes in physical chemical conditions (Bianchi, 2007). Conservative mixing processes are often considered to dominate DOM cycling in estuaries (e.g., Granskog et al., 2005; Guéguen et al., 2011; Kowalczuk et al., 2010; Markager et al., 2011; Retamal et al., 2007). However, significant deviations from the conservative mixing line can be observed when flocculation, resuspension, in situ production, photobleaching, and biological degradation occur (Alling et al., 2010; Gardner et al., 2005; Tzortziou et al., 2007). Additionally, photochemical transformations can impact estuarine DOM as terrestrial DOM components can be more photoreactive compared to marine components (Obernosterer and Benner, 2004; Shank et al., 2009). Previous studies of arctic estuaries estimated that between $6 \%$ and 10\% of DOM can be photomineralized (Bélanger et al., 2006; Osburn et al., 2009). For estuaries with long residence times, including the Nelson/Hayes system where the average residence time of river water is months in the coastal environment (Granskog et al., 2009), DOM photoalteration may have a significant influence on DOM distribution and composition (Dainard et al., 2015; Granskog, 2012; Helms et al., 2008, 2013; Moran et al., 2000; Osburn et al., 2009; Skoog et al., 1996; Timko et al., 2014). 
Climatic warming in high latitude environments can result in the reduction in sea ice and an increase in riverine flow to surface marine waters (Peterson et al., 2006). Both processes affect DOM distribution and composition. The reduction in sea ice cover can enhance light penetration and thus DOM photomineralization, a major sink of terrestrially derived DOM in coastal environments (Blough and Del Vecchio, 2002). The aim of this study was to investigate the changes in DOM characteristics induced by mixing with Hudson Bay water and sunlight irradiation. Specifically, the concentration and the composition of DOM were determined along an estuarine transect in the Nelson/Hayes estuary in summer 2009-2012. The fluorescence properties of DOM determined by excitation-emission matrix and parallel factor analysis (EEM-PARAFAC; Stedmon and Bro, 2008; Murphy et al., 2013) were used to assess the composition of FDOM along the river-coastal transect conducted in 2009-2012. The relationships between DOC, CDOM, FDOM, and salinity were investigated in order to establish a mixing model for accurate prediction of the quality and quantity of DOM exported in Hudson Bay. In addition, experimental light exposure treatments were performed to identify alterations to the DOM pool during photochemical processing.

\section{Materials and methods}

\subsection{Sample collection and processing}

Surface water samples (Fig. 1) were collected as part of the ArcticNet theme 3.1 project, during four summer cruises (July 26-August 03, 2009; August 21-27, 2010; September 13-17, 2011; August 27September 01, 2012). Additional samples were collected under the ice between March 02 and March 22, 2009, in the Nelson Estuary. Samples $(n=132)$ were collected across a salinity range of $0-28$ and immediately gravity filtered from Niskin bottles using precombusted glass-fiber filters $(0.7 \mu \mathrm{m}$ pore size, GF/F). DOC samples were stored frozen $\left(-20{ }^{\circ} \mathrm{C}\right)$, whereas $\mathrm{CDOM} / \mathrm{FDOM}$ samples were refrigerated $\left(4{ }^{\circ} \mathrm{C}\right)$ for $2-3$ months until analysis.

\subsection{Photodegradation experiments}

Seven 0.2- $\mu \mathrm{m}$ filtered (Nuclepore, Millipore) natural surface water samples (Fig. 1) were transferred to $12 \mathrm{~mL}$ quartz tubes with Teflon-faced silicone septa closures (acid washed and rinsed) and exposed to irradiation in an Atlas Suntest CPS + solar simulator equipped with a xenon arc lamp filtered to provide light in the wavelength range of $\sim 300 \mathrm{~nm}$ to $\sim 800 \mathrm{~nm}$. The light spectrum produced by the solar simulator is very close to that of natural sunlight. The 2 -day continuous solar simulator irradiation equates to $\sim 6.9$ days under Arctic summer solstice. Samples were collected at 4 time points $(12,24,36,48 \mathrm{~h})$ over a 48 -h time period. Each time point was sampled in duplicate for rivers and estuarine samples (S1-S6) and in quadruplicate for bay samples (S7). The dark controls were aluminum foil covered quartz tubes and kept in the solar simulator alongside the testing samples and collected at each sampling time. The samples were kept in a water bath at ambient temperature $\left(22-25^{\circ} \mathrm{C}\right)$ during photoirradiation.

DOM photobleaching absorbance and fluorescence values at time $t\left(a_{\mathrm{t}}\right)$ were fitted as follows:

$a_{t}=a_{0} * e^{-k t}$

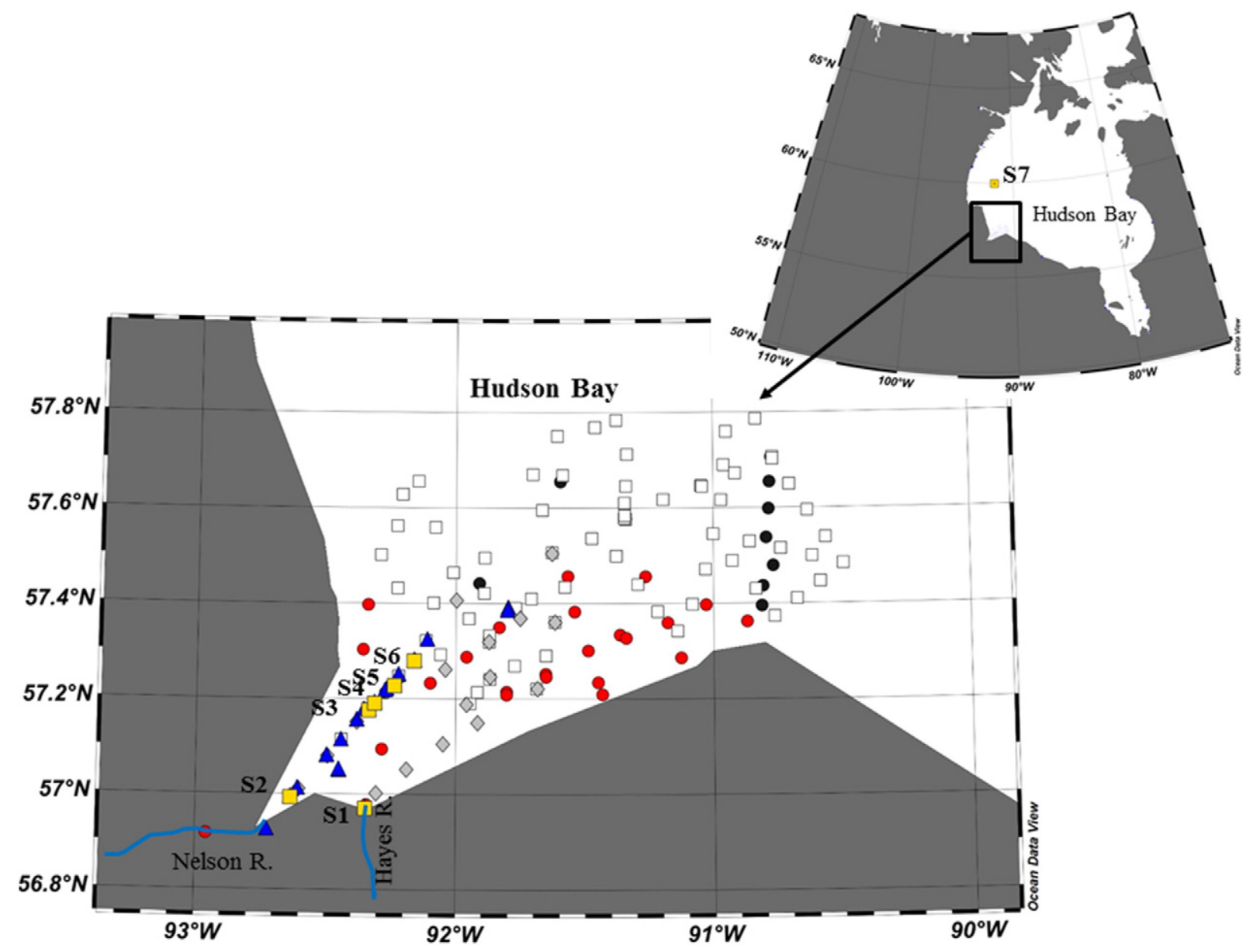

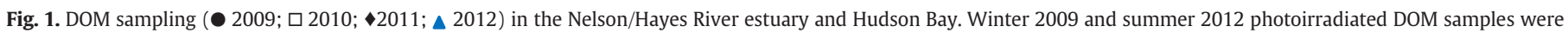
represented by red dots and orange squares. 
where $a_{0}$ is the initial value and $k$ is the measured first-order photobleaching rate coefficient. Photobleaching half-lives $\left(t_{1 / 2}\right)$ under simulated solar radiation were calculated using $k$ and by setting $a_{t} / a_{0}=0.5$.

\subsection{Chemical analyses}

DOC analysis was conducted by high-temperature combustion using a Shimadzu total organic carbon TOC-V analyzer (Mundy et al., 2010). Blanks were negligible and the standard error over three injections was typically $<2 \%$. Salinity (Sp; Millero, 2013) was measured using CTD conductivity calibrated with water samples measured with a Guildline Autosal 8400 salinometer.

The absorbance of CDOM samples was measured from 250 to $700 \mathrm{~nm}$ using a Shimadzu ultraviolet visible UV 2550 dual beam spectrophotometer and a 10-cm rectangular quartz cell (Guéguen et al., 2011). A 1-cm quartz cell was used for CDOM absorbance measurements of photoirradiated samples (S1-S6) because of the limited sample volumes available at each irradiation time; the quadruplicates of the photoexposed S7 samples were combined prior to CDOM measurement using a 10 -cm quartz cuvette. Ultrapure water from a Milli-Q system was used as reference. Samples were warmed at room temperature in the dark before measurement. The cuvette was thoroughly rinsed with Milli-Q water between samples. The measured absorbance A corrected for the Milli-Q blank was converted to an absorption coefficient a $\left(\mathrm{m}^{-1}\right)$ according to the equation:

$a_{\lambda}=2.303 \times A_{\lambda} / L$

where $\lambda$ is the wavelength and $L$ is the path length of the optical cell in meters. The slopes of absorption spectra $S_{275-295}$ and $S_{350-400}$ were extracted from the absorption data over the ranges $275-295 \mathrm{~nm}$ and 350-400 nm, respectively (Helms et al., 2008), using an exponential decay curve fitted (Guéguen and Kowalczuk, 2013).

\subsection{Fluorescence measurements and PARAFAC modeling}

A fluorescence spectrometer (Fluoromax 4, Horiba JobinYvon) was used to obtain the three-dimensional EEM spectra of the DOM samples with excitation wavelengths in the range of $250-500 \mathrm{~nm}$ in $5-\mathrm{nm}$ intervals and with emission wavelengths ranging from 300 to $600 \mathrm{~nm}$ in 5-nm intervals. The resulting EEMs were processed by (1) correcting for instrument biases using protocols suggested by the manufacturer, (2) subtracting an ultrapure water blank acquired daily to remove the Raman and Raleigh scattering peaks from the EEMs, and (3) correcting for the inner filter effects (Kothawala et al., 2013). Finally, the EEMs were normalized to the area of an ultrapure water Raman peak measured on the same day (Lawaetz and Stedmon, 2009). The fluorescence intensities were shown on a unified scale of Raman units (r.u.).

PARAFAC decomposes the complex mixtures of DOM fluorophores into its main components (Stedmon et al., 2003). PARAFAC analysis was carried out in Matlab R2012b using the DOMFluor toolbox (Stedmon and Bro, 2008). Two samples with extreme leverage were removed from the data set. The determination of the most suitable number of components was achieved by the split-half analysis and random initialization (Stedmon et al., 2003) whereby both halves were successfully validated. The model was constrained to nonnegative values (Stedmon et al., 2003), and no systematic residual was found in the modeled EEMs.

\section{Results and discussion}

\subsection{Fluorescent component analysis}

Five fluorescent components were identified using EEM-PARAFAC, including three humic-like (C1-C3) and two protein-like (C4-C5) components (Fig. 2). The five PARAFAC components found in the Nelson/Hayes system are common in river, estuarine, and coastal waters (e.g., Chari et al., 2012; Guéguen et al., 2011; Guo et al., 2011, 2014; Stedmon et al., 2003; Sun et al., 2014). C1 and C2 had excitation/ emission maxima at $330 / 465 \mathrm{~nm}$ and $<250 / 455 \mathrm{~nm}$, which are close to
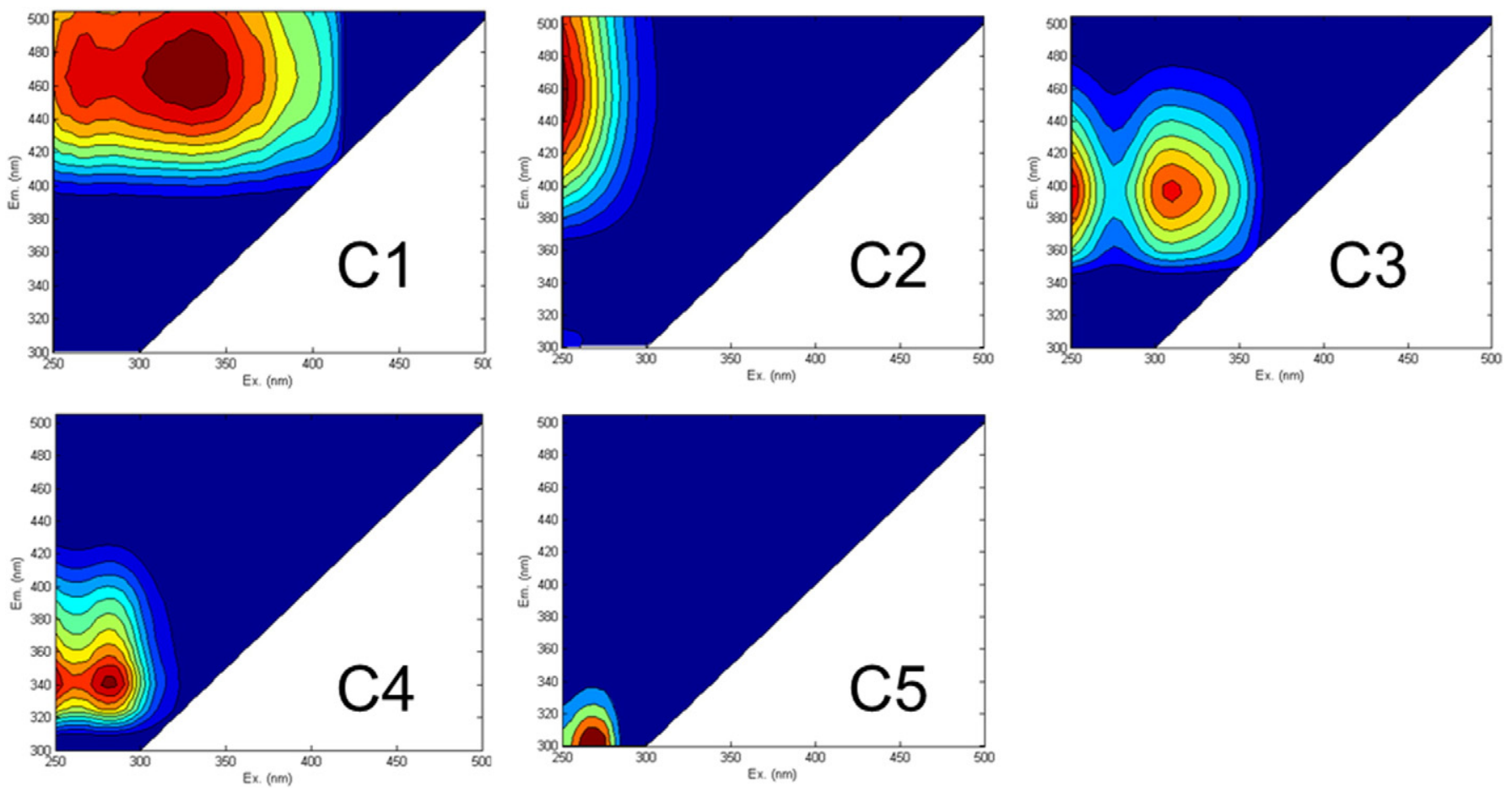

Fig. 2. Contour plots of five components validated by PARAFAC. Warmer colors represented greater fluorescence intensities. 
the traditionally defined terrestrial humic-like fluorescence peaks $C$ and A, respectively (Coble, 1996, 2007). Component C3 had excitation/ emission maxima at $<250(310) / 395 \mathrm{~nm}$, which is attributed to peaks A and M (Ishii and Boyer, 2012). Peak A is typical of terrestrial humiclike material (Coble, 1996), whereas peak $\mathrm{M}$ is attributed to marine sources (Coble, 1996; Coble et al., 1998) and more recently to microbially altered DOM (Stedmon and Markager, 2005). The fluorescence intensities of humic-like C1-C3 were very closely correlated $\left(r^{2}=0.98-0.99\right.$, $p<0.05$ ), suggesting similar sources and/or controlling factors. The last two PARAFAC components $\mathrm{C} 4-\mathrm{C} 5$ had an emission maximum at $<400 \mathrm{~nm}$ and are thus attributed to protein-like components. $\mathrm{C} 4$ had excitation/emission maxima at $280 / 345 \mathrm{~nm}$, similar to the tryptophanlike peak T (275/340 nm), whereas C5 had excitation/emission maxima at 265/300 nm, similar to the tryptophan-like peak T (Coble, 1996). Tyrosine and tryptophan-like components have been attributed to autochthonous sources (Mopper and Schultz, 1993; Yamashita et al., 2011) and tannin/lignin contribution (Cuss and Guéguen, 2015; Maie et al., 2008).

\subsection{DOM composition}

The DOC concentration ranged from 1.09 to $12.31 \mathrm{mg} \mathrm{L}^{-1}$, and the absorption coefficient at $355\left(a_{355}\right)$ varied from 0.42 to $18.84 \mathrm{~m}^{-1}$ over the 4-year survey in the Nelson/Hayes system (Fig. 3A-B). Despite significant variability at low salinities $(\mathrm{Sp} \sim 0)$, DOC and $a_{355}$ were strongly correlated at $\mathrm{Sp}>10\left(\mathrm{DOC}=0.83 \times a_{355}+1.63 ; r^{2}=0.88\right.$, $n=106)$. Noticeably, DOC and $a_{355}$ were 1.5 times higher in the Hayes River than in the Nelson River (12.3 vs $7.6 \mathrm{mg} \mathrm{L}^{-1}$ and 18.8 vs $9.2 \mathrm{~m}^{-1}$, respectively).

The spectral slope $\left(\mathrm{S}_{275-295}\right.$; Fig. $\left.3 \mathrm{C}\right)$ and $\mathrm{Sr}$ ranged from 0.015 to $0.025 \mathrm{~nm}^{-1}$ and from 0.86 to 1.49 , respectively. Similar ranges were reported in boreal rivers (Asmala et al., 2012; Guéguen et al., 2012) and estuaries (Asmala et al., 2012; Guo et al., 2007, 2014; Helms et al., 2008). Lower $S_{275-295}$ values are synonymous of higher DOM molecular weight and aromaticity (Guéguen and Cuss, 2011; Helms et al., 2008). Despite variability (Fig. 3C), fairly constant $\mathrm{S}_{275-295}$ values were found at $\mathrm{Sp}<20$ before increasing to higher $\mathrm{Sp}$. This decrease in DOM molecular weight is congruent with the decrease of terrestrial humic-like C1 abundance. The rise in $\mathrm{S}_{275-295}$ at higher salinity may be caused by additional sources of low molecular weight material such as production of low molecular weight (Cuss and Guéguen, 2015) protein-like (Fig. 3G-H) and/or enhanced photochemical degradation (Blough and Del Vecchio, 2002; Helms et al., 2008). Comparison of $S_{275-295}$ values between the freshwater end members showed that the Hayes River had lower $S_{275-295}$ values $\left(0.015\right.$ vs $0.018 \mathrm{~nm}^{-1}$ ), suggesting that DOM in Hayes estuary was more aromatic and higher in molecular weight than that in the Nelson.

The humic-like fluorescence intensities of C1-C3 (Fig. 3D-F) decreased with increasing distance from the river mouth, whereas patches of high protein-like intensities were locally found within the estuary (Fig. 3G-H). Like DOC and $a_{355}$, higher humic-like intensities were reported in the Hayes River compared to the Nelson River. Humic-like intensities were 30 times (i.e., C2 and C3) to 76 times (i.e., C1) higher in the Hayes River.

\subsection{Mixing behavior}

DOC, $a_{355}$, and humic-like $\mathrm{C} 1-\mathrm{C} 3$ displayed a distribution tightly coupled with salinity $\left(r^{2}=0.84,0.78\right.$, and $0.70-0.76$, respectively; Fig. 3A-F). These high $r^{2}$ values suggest that quasi-conservative mixing significantly impacts DOM behavior in the Nelson/Hayes estuary. It can be noted that DOC, $a_{355}$, and C1-C3 in winter 2009 were above the average conservative mixing lines. At any given salinity, DOC, $a_{355}$, and C1-C3 were higher in winter 2009 than in summer, suggesting reduced estuarine mixing in winter. The presence of sea ice in close proximity to the Nelson River mouth has been suggested to prevent freshwater mixing (Kuzyk et al., 2008) and thus terrestrial DOM mixing with bay water.
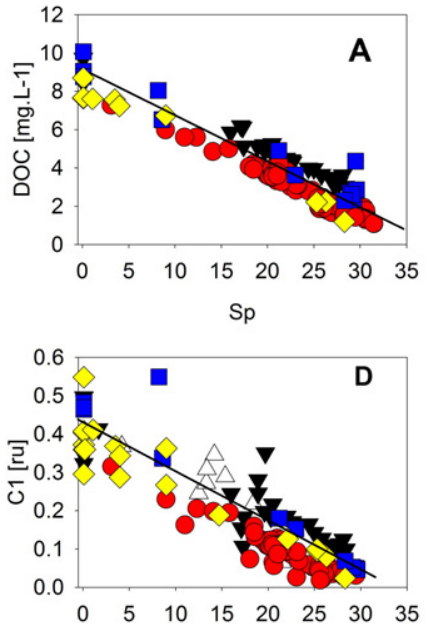

$\mathrm{Sp}$

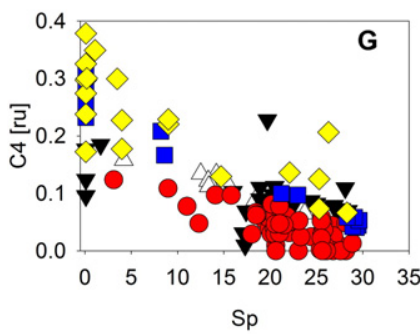

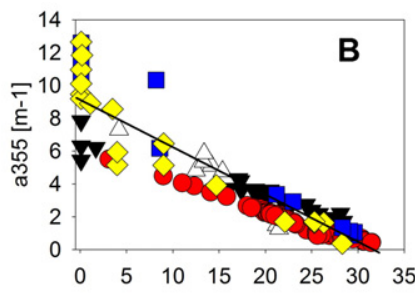

Sp
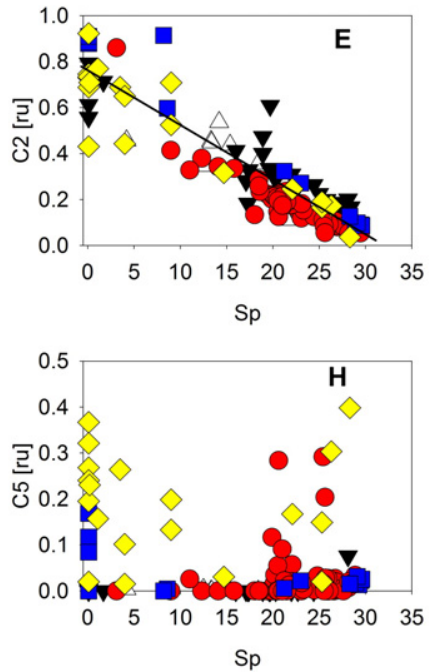

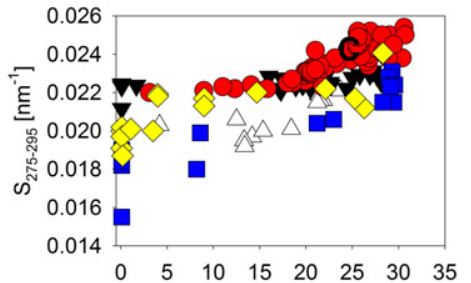

Sp

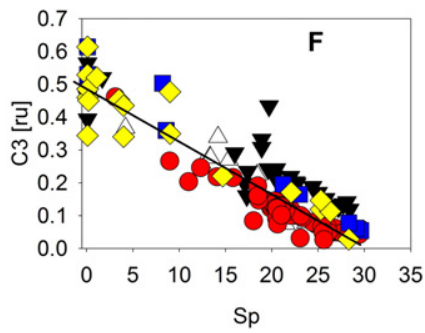

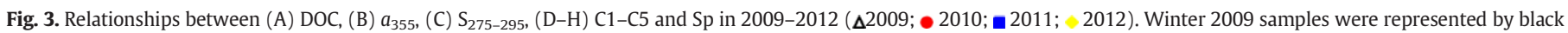
triangles $(\boldsymbol{\nabla})$. 

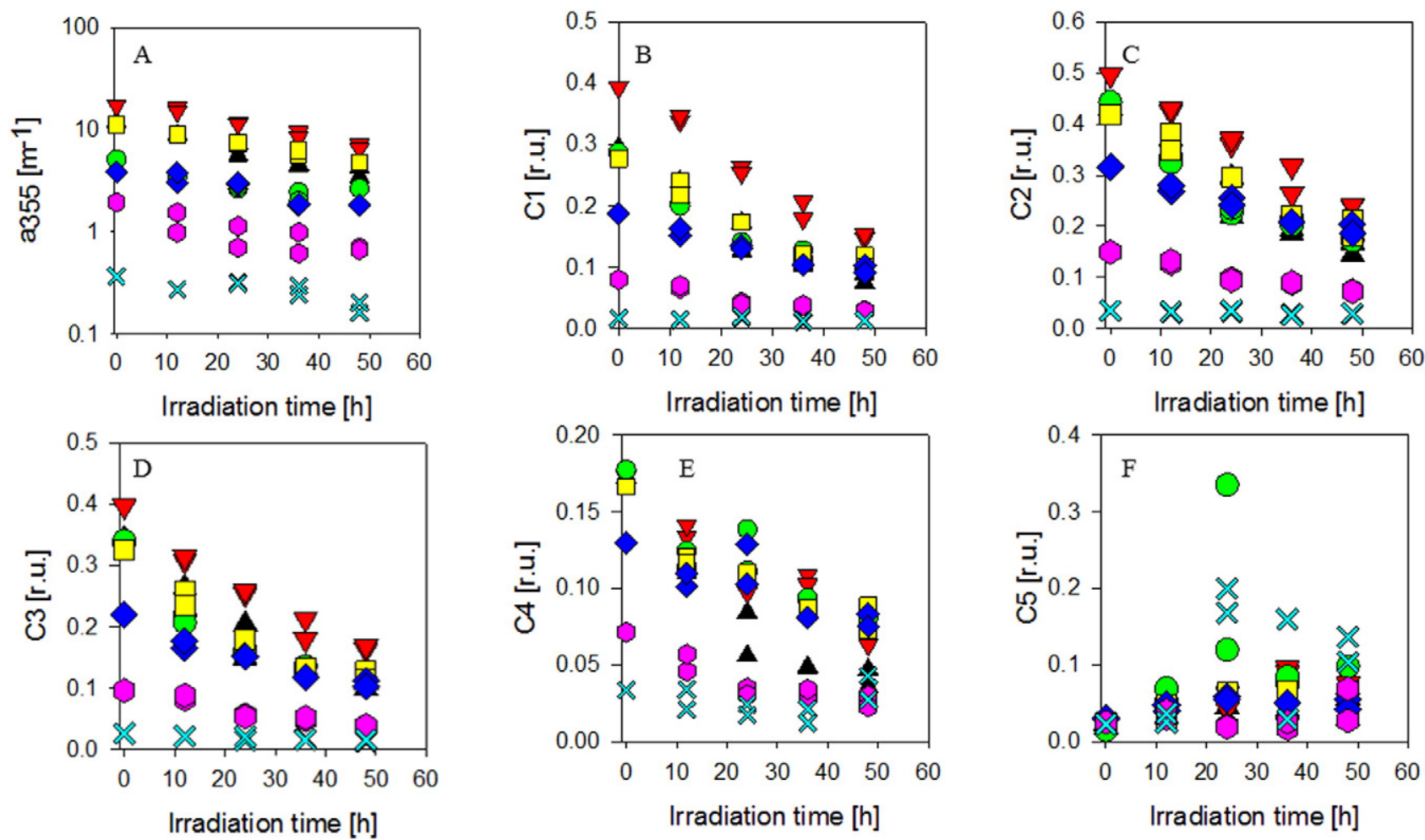

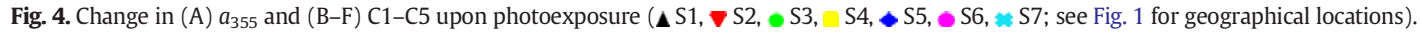

The residuals calculated between observed concentrations and the conservative mixing line averaged $-0.06 \pm 0.63 \mathrm{mg} \mathrm{L}^{-1}, 0.001 \pm$ $1.49 \mathrm{~m}^{-1}, 0.0001 \pm 0.073$ r.u., $-0.0001 \pm 0.111$ r.u., and $-0.0002 \pm$ 0.061 r.u. for DOC, $a_{355}$, and C1-C3, respectively. These errors were 12 , 3 , and 3-4 times lower than their respective average values reported at $\mathrm{Sp}=28-30$. Although the residuals were more variable at $\mathrm{Sp}<10$ likely due to the variability in river composition, no significant differences were found between residuals at low $(\mathrm{Sp}<10)$, mid $(\mathrm{Sp}=$ $10-20)$, and high salinity $(\mathrm{Sp}>20)(p>0.05)$. While in general DOC decreased with the increase in salinity (Fig. 3A; S1 A), deviations from the conservative mixing lines were occasionally observed for $a_{355}$ and humic-like $\mathrm{C} 1-\mathrm{C} 3$ at low to mid-salinities ( $\mathrm{Sp}<10-20$; Fig. S1B-E). The DOM removal by degradation (Granskog, 2012; Osburn et al., 2009) or adsorption to particles (Uher et al., 2001) leads to values falling below the mixing line (Markager et al., 2011; Stedmon and Markager, 2003). However, $a_{355}$ and humic-like removal were not systematically observed during the 4-year survey. For example, removal of $a_{355}$ was found at $\mathrm{Sp}<20$ in 2011-2012 but not during the 2010 survey. Further studies are required to better understand these temporal patterns.

The protein-like components C4-C5 (Fig. 3G-H; S1F-G) showed significant deviations from the ideal mixing line (i.e., conservative mixing), indicative of internal estuarine sources (Stedmon and Markager, 2003;
Sun et al., 2014). The tryptophan-like C4 intensity decreased with increasing salinity $(r=-0.78 ; n=57)$ before plateauing at $\mathrm{Sp}>20$. This contrasts with tyrosine-like C5, where significant inputs were found at low $(<10)$ and high salinity $(>20)$, whereas low C5 intensity was reported at intermediate salinity ( $\mathrm{Sp} \sim 10-20)$. The decoupling behavior between the two protein-like components indicated different sources and /or degradation rates within the estuary.

\subsection{DOM photodegradation}

Solar exposure resulted in substantial losses in DOM absorbance and fluorescence (Fig. 4). For the dark samples, there was almost no change in CDOM and FDOM intensities after 2-day exposure compared to the pre-irradiated samples, indicating no significant bacterial activity. The percentage of $a_{355}$ loss was $61-68 \%, 49-56 \%$, and $52 \%$ for river (S1-2), estuarine (S3-6), and bay samples (S7), respectively (Table 1). Also, $\mathrm{S}_{275-295}$ and $\mathrm{Sr}$ were consistently higher on irradiated samples relative to pre-irradiated samples. The marked increase in $\mathrm{S}_{275-295}$ and $\mathrm{Sr}$ with irradiation time was found for all samples. For example, Sr increased from 1.01 to 1.33 at S1-S2 and from 1.34 to 2.72 at S7. The increase in $\mathrm{S}_{275-295}$ and $\mathrm{Sr}$ suggests a decrease in molecular weight and aromaticity (Helms et al., 2008). (See Fig. 3.)

Table 1

Percent loss (\%loss) and parameters of first-order kinetics ( $k$ in $\mathrm{h}^{-1}$ and $\left.r^{2}\right)$ for $a_{355}$ and C1-C4.

\begin{tabular}{|c|c|c|c|c|c|c|c|c|c|c|c|c|c|c|c|}
\hline & \multicolumn{3}{|l|}{$a_{355}$} & \multicolumn{3}{|l|}{$\mathrm{C} 1$} & \multicolumn{3}{|l|}{$\mathrm{C} 2$} & \multicolumn{3}{|l|}{$\mathrm{C} 3$} & \multicolumn{3}{|l|}{$\mathrm{C} 4$} \\
\hline & $\%$ loss & $k\left[\mathrm{~h}^{-1}\right]$ & $r^{2}$ & \%loss & $k\left[\mathrm{~h}^{-1}\right]$ & $r^{2}$ & \%loss & $k\left[\mathrm{~h}^{-1}\right]$ & $r^{2}$ & $\%$ loss & $k\left[\mathrm{~h}^{-1}\right]$ & $r^{2}$ & $\%$ loss & $k\left[\mathrm{~h}^{-1}\right]$ & $r^{2}$ \\
\hline S1 & 60.64 & 0.021 & 0.97 & 27.56 & 0.022 & 0.98 & 33.78 & 0.016 & 0.96 & 28.87 & 0.019 & 0.98 & 9.79 & 0.0170 & 0.87 \\
\hline S2 & 68.27 & 0.024 & 0.94 & 23.58 & 0.028 & 0.95 & 36.39 & 0.022 & 0.94 & 26.00 & 0.025 & 0.95 & 10.80 & 0.0296 & 0.91 \\
\hline S3 & 48.75 & 0.022 & 0.94 & 23.41 & 0.019 & 0.87 & 34.13 & 0.017 & 0.90 & 27.24 & 0.021 & 0.95 & 13.65 & 0.0143 & 0.80 \\
\hline S4 & 56.47 & 0.018 & 0.99 & 24.18 & 0.023 & 0.96 & 34.80 & 0.018 & 0.97 & 28.34 & 0.023 & 0.95 & 12.46 & 0.0139 & 0.89 \\
\hline S5 & 51.25 & 0.018 & 0.87 & 21.25 & 0.014 & 0.96 & 35.78 & 0.010 & 0.96 & 24.90 & 0.015 & 0.97 & 14.64 & 0.0099 & 0.70 \\
\hline S6 & 51.87 & 0.022 & 0.99 & 18.89 & 0.024 & 0.94 & 35.47 & 0.016 & 0.96 & 22.71 & 0.022 & 0.94 & 16.94 & 0.0199 & 0.83 \\
\hline S7 & 51.52 & 0.013 & 0.91 & 12.22 & 0.011 & 0.58 & 25.79 & 0.005 & 0.86 & 19.54 & 0.013 & 0.81 & 25.16 & n.s. & n.s. \\
\hline
\end{tabular}

n.s. means not significant. 
Like $a_{355}, \mathrm{~S}_{275-295}$, and $\mathrm{Sr}$, large differences in fluorescence intensity were found after solar irradiation. However, the effects of photoirradiation depended on the PARAFAC component examined. Among all samples, the intensity of $\mathrm{C} 1-\mathrm{C} 3$ decreased after light exposure. C1 and C3 experienced a relatively lesser amount of photobleaching than did C2 (12-29\% vs 26-36\%; Table 1$)$. The relative abundances of C1-C4 were significantly lower after light exposure relative to dark treatments. For example, a $12 \%$ to $28 \%$ decrease in C1 abundance was found with the greatest loss found in river samples (S1-S2). Furthermore, the abundance in ultraviolet humic-like C2 (peak A; Coble, 1996) increased upon photoexposure at S1-S2 and S5-S6. The photoproduction of peak $\mathrm{A}$ has been reported in streams and coastal waters (Cawley et al., 2012; Lu et al., 2013; Stedmon et al., 2007). Unlike the North Pacific study (Helms et al., 2013), the intensity of protein-like C5 responded non-uniformly to light exposure in all samples. Proteinlike C5 intensity varied during the 48-h exposure, initially increasing and then decreasing markedly after 24-36 h exposure. Photoirradiation, however, significantly increased C5 intensity compared to dark incubated and initial treatments. The photoproduction of protein-like $\mathrm{C} 5$ has been reported in freshwater studies (McEnroe et al., 2013; Zhang et al., 2013).

Significant statistical fits $(p<0.05)$ to Eq. (1) (Table 1$)$ were found for $\mathrm{S} 1-\mathrm{S} 6, a_{355}$, and $\mathrm{C} 1-\mathrm{C} 4$, suggesting that first-order kinetics appropriately describe CDOM and FDOM photobleaching in the Nelson estuary system. Only $a_{355}$ and $\mathrm{C} 1-\mathrm{C} 3$ showed significant fit to first-order kinetics at S7. First-order rate constants ranged from 0.013 to $0.024 \mathrm{~h}^{-1}$ and, from 0.005 to $0.030 \mathrm{~h}^{-1}$ for $a_{355}$ and $\mathrm{C} 1-\mathrm{C} 4$, respectively. Photobleaching rates of humic-like DOM and $a_{355}$ generally decreased with increasing salinity. Although humic-like intensities were correlated in the Nelson system (see Section 3.1), the photobleaching rates $(k$, Table 1$)$ of $\mathrm{C} 1$ and $\mathrm{C} 3$ were significantly higher than that of $\mathrm{C} 2(p<0.05)$. This result suggests that humic-like components have different photoreactivity. Unlike pre-irradiated $a_{355}$ and PARAFAC intensities, the pre-irradiated $\mathrm{C} 2-\mathrm{C} 3$ abundances were positively correlated with $k\left(r^{2}=0.60\right.$ and 0.48 , respectively). Assuming that 2 days in the Suntest solar simulator was equivalent to 6.9 days during Arctic summer solstice, the estimated half-lives ranged from 4.9 to 9.9 days (average 5.4 days) at S1-S6. The Nelson/Hayes DOM half-lives were nearly equivalent to those found in the Mackenzie River (3.7-4.8 days for $\mathrm{a}_{330}$; Osburn et al., 2009) and in the Baltic Sea (0.5-3.0d for humiclike DOM; Skoog et al., 1996). These half-life values are likely underestimated as high turbidity in coastal Hudson Bay (Granskog, 2012) may limit light penetration and thus slow down photobleaching of DOM.

\section{Conclusions}

This study provided evidence of freshwater discharge of DOM to the Nelson/Hayes estuarine system in Hudson Bay and investigated the effect of photoirradiation on DOM concentration and composition. Despite some temporal losses, DOC, $a_{355}$, and humic-like DOM decreased linearly with increasing salinity $\left(r^{2}=0.70-0.84\right)$ over the 4-year survey in the Nelson/Hayes estuary system. These negative linear relationships were robust enough such that DOC, $a_{355}$, and humic-like could be used as tracers of coastal mixing in the Nelson/Hayes estuary system. Unlike protein-like component, CDOM and humic-like FDOM showed significant photo reduction in their intensities. Reported half-lives (4.9-9.9 days) were comparable to previous studies in the Mackenzie estuary system. In conclusion, this study could be used as a reference for future studies evaluating the fate and distribution of terrestrial DOM in the Nelson/Hayes system, where additional hydroelectric generating capacity is being built.

Supplementary data to this article can be found online at http://dx. doi.org/10.1016/j.jmarsys.2016.05.005.

\section{Acknowledgments}

Funding for this study was provided by the Canada Research Chairs program and the Natural Sciences and Engineering Research Council of Canada (CG), and ArcticNet Theme 3.1 (TP). We would like to acknowledge the captains, crews, and scientists from of the CCGS Amundsen. We also thank Manitoba Hydro for logistical support during the 2009 winter survey. Two anonymous reviewers provided insightful comments that helped improve the manuscript.

\section{References}

Alling, V., Sanchez-Garcia, L., Porcelli, D., Pugach, S., Vonk, J.E., van Dongen, D., Mörth, C.-M., Anderson, L.G., Sokolov, A., Andersson, P., Humborg, C., Semiletov, I., Gustafsson, O., 2010. Non-conservative behavior of dissolved organic carbon across the Laptev and East Siberian seas. Glob. Biogeochem. Cycles 24, GB4033. http://dx.doi.org/10.1029/2010GB003834.

Asmala, E., Stedmon, C.A., Thomas, D.N., 2012. Linking CDOM spectral absorption to dissolved organic carbon concentrations and loadings in boreal estuaries. Estuar. Coast. Shelf Sci. 111, 107-117

Bélanger, S., Xie, H., Krotkov, N., Larouche, P., Vincent, W.F., Babin, M., 2006. Photomineralization of terrigenous dissolved organic matter in Arctic coastal waters from 1979 to 2003: interannual variability and implications of climate change. Glob. Biogeochem. Cycles 20, GB4005. http://dx.doi.org/10.1029/2006 GB002708.

Bianchi, T.S., 2007. Biogeochemistry of estuaries. Oxford University Press, New York (706 pp.).

Blough, N.V., Del Vecchio, R., 2002. Chromophoric DOM in the coastal environment. In: Hansell, D.A., Carlson, C.A. (Eds.), Biogeochemistry of Marine Dissolved Organic Matter. Associated Press, San Diego, pp. 509-546.

Cawley, K., Wolski, P., Mladenov, N., Jaffe, R., 2012. Dissolved organic matter biogeochemistry along a transect of the Okavango Delta, Botswana, Wetlands. http://dx.doi.org/ 10.1007/s13157-012-0281-0.

Chari, N.V.H.K., Sarma, N.S., Pandi, S.R., Murthy, K.N., 2012. Seasonal and spatial constraints of fluorophores in the Midwestern Bay of Bengal by PARAFAC analysis of excitation emission matrix spectra. Estuar. Coast. Shelf Sci. 100, 162-171.

Coble, P.G., 1996. Characterization of marine and terrestrial DOM in seawater using excitation-emission matrix spectroscopy. Mar. Chem. 51, 325-346.

Coble, P.G., 2007. Marine optical biogeochemistry e the chemistry of ocean color. Chem. Rev. 107, 402-418.

Coble, P.G., Del Castillo, C.E., Avril, B., 1998. Distribution and optical properties of CDOM in the Arabian Sea during the 1995 southwest monsoon. Deep-Sea Res. II 45, 2195-2223.

Cuss, C.W., Guéguen, C., 2015. Relationships between molecular weight and fluorescence properties for size-fractionated dissolved organic matter from fresh and aged sources. Water Res. 68, 487-497.

Dainard, P.G., Guéguen, C., McDonald, N., Williams, W.J., 2015. Photobleaching of fluorescent dissolved organic matter in Beaufort Sea and North Atlantic Subtropical Gyre. Mar. Chem. 177, 630-637.

Déry, S.J., Mlynowski, T.J., Hernández-Henríquez, M.A., Straneo, F., 2011. Interannual variability and interdecadal trends in Hudson Bay streamflow. J. Mar. Syst. 88, 341-351.

Déry, S.J., Stieglitz, M., McKenna, E.C., Wood, E.F., 2005. Characteristics and Trends of River Discharge into Hudson, James, and Ungava Bays, 1964-2000.

Gardner, G.B., Chen, R.F., Berry, A., 2005. High-resolution measurements of chromophoric dissolved organic matter (CDOM) in the Neponset River Estuary, Boston Harbor, MA Mar. Chem. 96, 137-154.

Granskog, M.A., Kaartokallio, H., Thomas, D.N., Kuosa, H., 2005. Influence of freshwater inflow on the inorganic nutrient and dissolved organic matter within coastal sea ice and underlying waters in the Gulf of Finland (Baltic Sea). Estuar. Coast. Shelf Sci. $65,109-122$

Granskog, M.A., 2012. Changes in spectral slopes of colored dissolved organic matter absorption with mixing and removal in a terrestrially dominated marine system. Mar. Chem. 134-135, 10-17.

Granskog, M.A., Kuzyk, Z.Z.A., Azetsu-Scott, K., Macdonald, R.W., 2011. Distributions of runoff, sea ice melt and brine using $\delta^{18} \mathrm{O}$ and salinity data-a new view on freshwater cycling in Hudson Bay. J. Mar. Syst. 88, 362-374.

Granskog, M.A., Macdonald, R.W., Kuzyk, Z.Z.A., Senneville, S., Mundy, C.J., Barber, D.G., Stern, G.A., Saucier, F., 2009. Coastal conduit in southwestern Hudson Bay (Canada) in summer: rapid transit of freshwater and significant loss of colored dissolved organic matter. J. Geophys. Res. 114. http://dx.doi.org/10.1029/2009JC005270.

Guéguen, C., Cuss, C.W., 2011. Characterization of aquatic dissolved organic matter by asymmetrical flow field-flow fractionation coupled to UV-Visible diode array and excitation emission matrix fluorescence. J. Chromatogr. A 1218, 4188-4198.

Guéguen, C., Kowalczuk, P., 2013. Colored dissolved organic matter in frontal zones. In: Belkin, I.M. (Ed.), Chemical Oceanography of Frontal Zones, Hdb Env Chem. SpringerVerlag, Berlin Heidelberg http://dx.doi.org/10.1007/698_2013_244.

Guéguen, C., Burns, D.C., McDonald, A., Ring, B., 2012. Structural and optical characterization of dissolved organic matter from the lower Athabasca River, Canada. Chemosphere 87, 932-937.

Guéguen, C., Granskog, M.A., McCullough, G., Barber, D.G., 2011. Characterization of colored dissolved organic matter in Hudson Bay and Hudson Strait using Parallel Factor Analysis. J. Mar. Syst. 88, 423-433. 
Guo, W., Stedmon, C.A., Han, Y., Wu, F., Yu, X., Hu, M., 2007. The conservative and nonconservative behavior of chromophoric dissolved organic matter in Chinese estuarine waters. Mar. Chem. 107, 357-366.

Guo, W., Yang, L., Hong, H., Stedmon, C.A., Wang, F., Xu, J., Xie, Y., 2011. Assessing the dynamics of chromophoric dissolved organic matter in a subtropical estuary using parallel factor analysis. Mar. Chem. 124, 125-133.

Guo, W., Yang, L., Zhai, W., Chen, W., Osburn, C.L., Huang, X., Li, Y., 2014. Runoff-mediated seasonal oscillation in the dynamics of dissolved organic matter in different branches of a large bifurcated estuary-the Changjiang Estuary. J. Geophys. Res. Biogeosci. 119. http://dx.doi.org/10.1002/2013JG002540.

Helms, J.R., Stubbins, A., Perdue, E.M., Green, N.W., Chen, H., Mopper, K., 2013. Photochemical bleaching of oceanic dissolved organic matter and its effect on absorption spectral slope and fluorescence. Mar. Chem. 155, 81-91.

Helms, J.R., Stubbins, A., Ritchie, J.D., Minor, E.C., Kieber, D.J., Mopper, K., 2008. Absorption spectral slopes and slope ratios as indicators of molecular weight, source and photobleaching of chromophoric dissolved organic matter. Limnol. Oceanogr. 53, 955-969. http://dx.doi.org/10.4319/lo.2008.53.3.0955.

Ishii, S.K.L., Boyer, T.H., 2012. Behavior of reoccurring PARAFAC components in fluorescent dissolved organic matter in natural and engineered systems: a critical review. Environ. Sci. Technol. 46, 2006-2017.

Kothawala, D.N., Murphy, K.R., Stedmon, C.A., Weyhenmeyer, G.A., Tranvik, L.J., 2013. Inner filter correction of dissolved organic matter fluorescence. Limnol. Oceanogr. Methods 11, 616-630.

Kowalczuk, P., Cooper, W.J., Durako, M.J., Kahn, A.E., Gonsior, M., Young, H., 2010. Characterization of dissolved organic matter fluorescence in the South Atlantic Bight with use of PARAFAC model: relationships between fluorescence and its components, absorption coefficients and organic carbon concentrations. Mar. Chem. 118, 22-36.

Kuzyk, Z.A., Macdonald, R.W., Granskog, M.A., Scharien, R.K., Galley, R.J., Michel, C., Barber, C., Barber, D., Stern, G., 2008. Sea ice, hydrological and biological processes in the Churchill River estuary region, Hudson Bay. Estuar. Coast. Shelf Sci. 77, 369-384.

Lawaetz, A.J., Stedmon, C.A., 2009. Fluorescence intensity calibration using the Raman scatter peak of water. Appl. Spectrosc. 63 (8), 936-940.

Lu, Y., Bauer, J.E., Canuel, E.A., Yamashita, J., Chambers, R.M., Jaffé, R., 2013. Photochemical and microbial alteration of dissolved organic matter in temperate headwater streams associated with different land use. J. Geophys. Res. Biogeosci. 118, 566-580. http://dx. doi.org/10.1002/jgrg.20048.

Maie, N., Pisani, O., Jaffé, R., 2008. Mangrove tannins in aquatic ecosystems: their fate and possible influence on dissolved organic carbon and nitrogen cycling. Limnol. Oceanogr. 53, 160-171.

Markager, S., Stedmon, C.A., Sondergaard, M., 2011. Seasonal dynamics and conservative mixing of dissolved organic matter in the temperate eutrophic estuary Horsens Fjord. Estuar. Coast. Shelf Sci. 92, 376-388.

McEnroe, N.A., Williams, C.J., Xenopoulos, M.A., Porcal, P., Frost, P.C., 2013. Distinct optical chemistry of dissolved organic matter in urban pond ecosystems. PLoS One 8 http:// dx.doi.org/10.1371/journal.pone.0080334.

Millero, F.J., 2013. Chemical oceanography. 4th Edition. CRC Press, Boca Raton, p. 571.

Mopper, K., Schultz, C.A., 1993. Fluorescence as a possible tool for studying the nature and water column distribution of DOC components. Mar. Chem. 41, 229-238.

Moran, M.A., Sheldon Jr., W.M., Zepp, R.G., 2000. Carbon loss and optical property changes during long-term photochemical and biological degradation of estuarine dissolved organic matter. Limnol. Oceanogr. 45, 1254-1264.
Mundy, C.J., Gosselin, M., Starr, M., Michel, C., 2010. Riverine export and the effects of circulation on dissolved organic carbon in the Hudson Bay system, Canada. Limnol. Oceanogr. 55, 315-323.

Murphy, K.R., Stedmon, C.A., Graeber, D., Bro, R., 2013. Fluorescence spectroscopy and multi-way techniques. PARAFAC. Anal. Methods 5, 6557-6566.

Obernosterer, I., Benner, R., 2004. Competition between biological and photochemical processes in the mineralization of dissolved organic carbon. Limnol. Oceanogr. 49 $117-124$.

Osburn, C.L., Retamal, L., Vincent, W.F., 2009. Photoreactivity of chromophoric dissolved organic matter transported by the Mackenzie River to the Beaufort Sea. Mar. Chem. $115,10-20$.

Peterson, B.J., McClelland, J., Curry, R., Holmes, R.M., Walsh, J.E., Aagaard, K., 2006. Trajectory shifts in the Arctic and subarctic freshwater cycle. Science 313, 1061-1066.

Retamal, L., Vincent, W.F., Martineau, C., Osburn, C.L., 2007. Comparison of the optical properties of dissolved organic matter in two river-influenced coastal regions of the Canadian Arctic. Estuar. Coast. Shelf Sci. 72, 261-272.

Shank, G.C., Nelson, K.K., Montagna, P.A., 2009. Importance of CDOM distribution and photoreactivity in a shallow Texas estuary. Estuar. Coasts 32, 661-677. http://dx. doi.org/10.1007/s12237-009-9159-7.

Skoog, A., Wedborg, M., Fogelqvist, E., 1996. Photobleaching of fluorescence and the organic carbon concentration in a coastal environment. Mar. Chem. 55, 333-345.

Stedmon, C.A., Markager, S., Tranvik, L., Kronberg, L., Slatis, T., Martinsen, W., 2007. Photochemical production of ammonium and transformation of dissolved organic matter in the Baltic Sea. Mar. Chem. 104, 227-240.

Stedmon, C.A., Bro, R., 2008. Characterizing dissolved organic matter fluorescence with parallel factor analysis: a tutorial. Limnol. Oceanogr. Methods 6, 572-579.

Stedmon, C.A., Markager, S., 2003. Behavior of the optical properties of colored dissolved organic matter under conservative mixing. Estuar. Coast. Shelf Sci. 57, 973-979.

Stedmon, C.A., Markager, S., 2005. Tracing the production and degradation of autochthonous fractions of dissolved organic matter by fluorescence analysis. Limnol. Oceanogr. 50, 1415-1426.

Stedmon, C.A., Markager, S., Bro, R., 2003. Tracing dissolved organic matter in aquatic environments using a new approach to fluorescence spectroscopy. Mar. Chem. 82, 239-254.

Sun, Q., Wang, C., Wang, P., Hou, J., Ao, Y., 2014. Absorption and fluorescence characteristics of chromophoric dissolved organic matter in the Yangtze Estuary. Environ. Sci. Pollut. Res. 21, 3460-3473.

Timko, S.A., Romera-Castillo, C., Jaffé, R., Cooper, W.J., 2014. Photoreactivity of natural dissolved organic matter from fresh to marine waters in the Florida Everglades, USA. Environ. Sci.: Processes Impacts 16, 866.

Tzortziou, M., Osburn, C.L., Neale, P.J., 2007. Photobleaching of dissolved organic material from a tidal marsh-estuarine system of the Chesapeake Bay. Photochem. Photobiol 83, 782-792.

Uher, G., Hughes, C., Henry, G., Upstill-Goddard, R.C., 2001. Non-conservative mixing behavior of colored dissolved organic matter in a humic-rich, turbid estuary. Geophys Res. Lett. http://dx.doi.org/10.1029/2000GL012509.

Yamashita, Y., Panton, A., Mahaffey, C., Jaffé, R., 2011. Assessing the spatial and temporal variability of dissolved organic matter in Liverpool Bay using excitation emission matrix fluorescence and parallel factor analysis. Ocean Dyn. 61, 569-579.

Zhang, Y., Liu, X., Osburn, C.L., Wang, M., Qin, B., Zhou, Y., 2013. Photobleaching response of different sources of chromophoric dissolved organic matter exposed to natural solar radiation using absorption and excitation-emission matrix spectra. PLoS One http://dx.doi.org/10.1371/journal.pone.0077515. 